\title{
Residual effect of winter undernutrition applied over the first four lactations in dairy cows
}

\author{
JB Coulon ${ }^{1}$, A Ollier ${ }^{2}$ \\ 1 Laboratoire adaptation des herbivores aux milieux; \\ 2 Laboratoire sous-nutrition des ruminants, Centre de recherche Inra de Theix, \\ 63122 Saint-Genès-Champanelle, France
}

(Received 10 August 1995; accepted 21 November 1995)

\begin{abstract}
Summary - During the first 12 weeks of their fifth lactation, 29 cows received ad libitum a diet composed of $55 \%$ maize silage and $45 \%$ concentrate. During their first four lactations, these cows received a winter ration composed of hay and grass silage, supplemented at three levels $(H, M$ and $L)$ of concentrate allocation. Over the summer period, all animals had been turned out to pasture together. Between the fourth and fifth lactation, milk production of the first 12 weeks of lactation increased by, respectively, $3.7,1.9$ and $5.4 \mathrm{~kg} /$ day in groups $\mathrm{H}, \mathrm{M}$ and $\mathrm{L}$. Whatever the group, these increases were highly variable among cows. This variability was explained by the variations of nutritive supply between the fourth and the fifth lactation, due to the differences in feed intake. This trial demonstrates that cows submitted to severe undernutrition over their first four lactations maintain a large response ability when fed liberally.
\end{abstract}

dairy cows / milk production / long-term effects / level of feeding

Résumé - Effet résiduel d'une sous-alimentation énergétique hivernale appliquée pendant les quatre premières lactations. Au cours des 12 premières semaines de leur cinquième lactation, 29 vaches laitières ont reçu, à volonté, un régime composé de $55 \%$ d'ensilage de maïs et $45 \%$ de concentré. Au cours de leurs quatre premières lactations, ces vaches avaient reçu une ration à base d'ensilage d'herbe et de foin, complémentée à trois niveaux d'apports de concentré ( $H, M$ et $L$ ). Au cours de la période estivale tous les animaux avaient étaient conduits ensemble, au pâturage. Entre la quatrième et la cinquième lactation, la production laitière moyenne des 12 premières semaines de lactation a augmenté de respectivement $3,7,1,9$ et $5,4 \mathrm{~kg}$ dans les lots $H, M$ et $L$. Ces augmentations ont été très variables d'une vache à l'autre et ont été liées aux variations des quantités ingérées entre les deux lactations. Cet essai montre que des vaches sous-alimentées durant les premiers mois de leurs quatre premières lactations sont capables de réagir fortement à une alimentation libérale en cinquième lactation.

vache laitière / production laitière / effet à long terme / niveau d'alimentation 


\section{INTRODUCTION}

The ability of dairy cows to achieve their production potential following extended periods of feeding restriction has been the subject of several long-term studies (Broster et al, 1993). According to several authors, it appears that residual effects of treatments of one lactation on another can exist to a greater or lesser degree (Wiktorsson, 1979; Broster et al, 1989; Berg and Ekern, 1993), in particular when cows have been underfed from their first lactation. In the majority of these trials, energy undernutrition was applied throughout the entire lactation but only spanning two or three lactations. In a long-term trial spanning four lactations with cows that began the experiment in their first lactation, we observed that energy undernutrition applied over the winter (140 days on average) led to a considerable cumulative effect on production at the beginning, but not over the entire lactation. This is due to the ability of multiparous cows to compensate during time spent at pasture for part of the production deficit, contrary to primiparous cows (Coulon et al, 1994, 1996). The aim of this trial was to study the effect of feeding level during the first four lactations on the production performances of several cows of this long-term study, managed under liberal feeding conditions in their fifth lactation.

\section{MATERIALS AND METHODS}

\section{Animals and feeding}

Among the cows remaining from this long-term study, 33 whose expected calving date in fifth lactation was before 15 January were retained for this experiment. Four of them were discarded because of abortion (1), milk fever (1) and heart attack at calving (2). Thus, only 29 cows of Holstein (15) or Montbéliarde (14) breed in their fifth lactation were used in this trial covering a period from 4 weeks before to 12 weeks after their fifth calving. The mean date of calving was 4 December (ranging between 2 November and 18 January). These cows entered the experiment over 3 consecutive years (nine to ten cows per year). During their first four lactations these cows received, over the winter, a diet composed of hay (4 kg/day) and grass silage from native mountain grassland ad libitum and supplemented with concentrate, distributed at three levels of allocation: high ( $\mathrm{H}$, six cows), medium ( $\mathrm{M}$, eight cows) and low ( $L, 15$ cows). At pasture, all cows were managed together. The experimental conditions of these first four lactations have been described elsewhere (Coulon et al, 1994, 1996). These cows had spent a mean of 139 days on experimental treatments during their successive lactations. The distribution of the cows between years, breeds and treatments during the first four lactations is given in table $\mathrm{I}$.

At least 1 month prior to their presumed date of fifth calving, these cows were taken to another INRA experimental farm where they were fed liberally until in their 12th week of lactation. Until calving, they received a diet composed of maize silage (ad libitum) and hay ( $1 \mathrm{~kg} /$ day). During the last 3 weeks of gestation, they also received 1,2 and $2 \mathrm{~kg} /$ day of concentrate, as well as 0,0 and $1 \mathrm{~kg} /$ day of soya-bean meal. From calving, all cows received a diet composed of 60 (year 1 ) or $55 \%$ (years 2 and 3 ) maize silage, $10 \%$ soyabean meal and $30 \%$ concentrate $(35 \%$ years 2 and 3 ), as well as $1 \mathrm{~kg} /$ day of hay and $200 \mathrm{~g} /$ day of a mineral additive $(60 \mathrm{~g} \mathrm{P}, 230 \mathrm{~g} \mathrm{Ca}, 30 \mathrm{~g} \mathrm{Mg}$ per $\mathrm{kg}$ ). The highest producing cows (expected maximal production above $38 \mathrm{~kg} /$ day) also received a supplementary $1 \mathrm{~kg} /$ day of concentrate as from the 3rd week of lactation. Feed characteristics are reported in table II

\section{Measurements and statistical analysis}

Milk production and chemical composition were individually measured twice weekly. Cows were weighed at calving (double weighing) and then every 2 weeks. Their body score was estimated by handling (score between 0 and 5) at calving, in the 6 th and the 12th week of lactation. Feed intakes were measured three times a week. Energy and nitrogen balances were computed from the difference between feed input and the animals' requirements, using the UFL (energy) and PDI (nitrogen) systems (Inra, 1989). 
Table I. Distribution of the cows over breeds, years and treatment during the first four lactations.

\begin{tabular}{|c|c|c|c|c|c|}
\hline \multirow{2}{*}{$\begin{array}{l}\text { Treatment during } \\
\text { the first four lactations }\end{array}$} & \multirow[t]{2}{*}{ Breed } & \multicolumn{3}{|c|}{ Year } & \multirow[t]{2}{*}{ Tota } \\
\hline & & 1 & 2 & 3 & \\
\hline- & & & & $\cdots$ & \\
\hline $\mathrm{H}$ & $\mathrm{HO}$ & 1 & 0 & 1 & 2 \\
\hline & MO & 1 & 1 & 2 & 4 \\
\hline$M$ & $\mathrm{HO}$ & 1 & 1 & 2 & 4 \\
\hline & MO & 3 & 1 & 0 & 4 \\
\hline L & $\mathrm{HO}$ & 2 & 5 & 2 & 9 \\
\hline & MO & 2 & 1 & 3 & 6 \\
\hline Total & & 10 & 9 & 10 & 29 \\
\hline
\end{tabular}

H: high; M: medium; L: low levels; HO: Holstein; MO: Montbéliarde.

Table II. Composition of food a.

$\begin{array}{lcccc} & \text { Hay } & \text { Maize silage } & \text { Concentrate } & \text { Soya-bean meal } \\ - & & & & \\ \text { Dry matter (DM) (\%) } & 87.4 & 31.0^{2} & 88.2 & 88.3 \\ \text { Crude protein }(\mathrm{g} / \mathrm{kg} \mathrm{DM}) & 78 & 80 & 178 & 523 \\ \text { Acid detergent fiber }(\mathrm{g} / \mathrm{kg} \mathrm{DM}) & 368 & 246 & 165 & 62 \\ \text { UFL }(/ \mathrm{kg} \mathrm{DM}) & 0.63 & 0.90 & 1.05 & 1.17 \\ \text { PDIN }(\mathrm{g} / \mathrm{kg} \text { DM) } & 55 & 48 & 128 & 371 \\ \text { PDIE }(\mathrm{g} / \mathrm{kg} \text { DM) } & 68 & 65 & 124 & 354 \\ \end{array}$

a Means of the 3 years; ${ }^{2}$ corrected to allow for dry matter (DM) losses during oven-drying according to Dulphy and Demarquilly (1981).

The analysis of results was carried out on 29 cows for the variables of the very beginning of lactation (live weight and body score at calving, maximal daily production), and on 28 cows for those concerning the complete experimental period. One cow of group $\mathrm{H}$ was culled from the trial in the 5th week of lactation due to severe mastitis. Performances were processed by analysis of variance (GLM procedure, SAS, 1987) by introducing into the model feeding level during former lactations, breed and year, as well as the reference milk production of animals (production of the first 3 weeks of the first lactation; Coulon et al, 1994).

\section{RESULTS}

Over the first 12 weeks of lactation, dry matter (DM) intake varied between 19.8 (group $\mathrm{M}$ ) and $21.5 \mathrm{~kg} /$ day (group H). The corresponding energy intakes were, respectively, 21.0, 19.4 and 19.9 UFL/day for groups $\mathrm{H}$, $M$ and $L$, that is an increase of 2.9, 3.1 and 4.6 UFL/day as compared to the fourth lactation (table III).

Group $\mathrm{H}$ cows produced more milk $(P<0.05)$ than those of groups $\mathrm{L}(+2.6$ 
Table III. Some characteristics of performance in fifth lactation and differences in performances between fourth and fifth lactations and depending on the level of concentrate allocation during the first four lactations.

Group

No of cows

Calving date

Reference milk production (kg/day)

Fifth lactation

Live weight at calving $(\mathrm{kg})$

Body condition score at calving

Peak production ( $\mathrm{kg} / \mathrm{day})$

Weeks 1-12

Milk (kg/day)

Fat-corrected milk (kg/day)

$\mathrm{DM}$ intake $(\mathrm{kg} /$ day)

Fat content $(\mathrm{g} / \mathrm{kg})$

Protein content $(\mathrm{g} / \mathrm{kg})$

Energy balance (UFL/day)

Empty body weight change $(\mathrm{kg})^{b}$

Body condition score change $(\mathrm{kg})^{\mathrm{b}}$
H

$M$

$L$

Residual SD

Significance a

Differences between fourth and fifth lactations

Milk (kg/day)

Fat-corrected milk (kg/day)

Energy supply (UFL/day)

Live weight at calving $(\mathrm{kg})$

Peak production ( $\mathrm{kg} /$ day)

Body condition score at calving

$\begin{array}{ccc}6 & 8 & 15 \\ 5 \mathrm{Dec} & 1 \mathrm{Dec} & 4 \mathrm{Dec} \\ 16.3 & 19.4 & 17.2\end{array}$

$\begin{array}{lll}676 & 682 & 681 \\ 2.5 & 2.8 & 2.8\end{array}$

$\begin{array}{lll}39.8 & 33.8 & 38.5\end{array}$

35.5

32.1

21.5

33.5

28.7

$-0.8$

$-30$

$-0.4$

\section{6}

32.9

30.6

20.4

19.8

37.0

34.9

30.4

$\begin{array}{ll}-0.3 & -0.8\end{array}$

$\begin{array}{ll}-17 & -22\end{array}$

$-0.4 \quad-0.5$

$+3.7+1.9+5.4$

$+3.7+2.4+5.0$

$+2.9+3.1+4.6$

$+22+15$

$+3.3+3.6$

$+9$

$+7.4$

$\begin{array}{lll}+0.6 & +0.6 \quad+0.7\end{array}$
55

0.5

4.5

NS

NS

3.9

3.8

1.7

2.9

1.4

1.7

31

0.4

$+3.4$

3.2

1.4

38

3.2

0.5

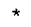

NS

NS

NS

$* \star \star$

NS

NS

NS

NS

NS

NS

**

NS

a * $P<0.1 ;{ }^{* *} P<0.05 ;{ }^{* \star *} P<0.01 ;$ NS: not significant; ${ }^{b}$ between weeks 12 and 1

$\mathrm{kg} /$ day) and $M(+5.9 \mathrm{~kg} /$ day $)$. This difference is greatly reduced and no longer significant if we consider the production of fatcorrected milk $(+1.5$ and $+3.9 \mathrm{~kg} / \mathrm{day}$, respectively, $P>0.1$ ), due to a lower fat concentration in group $\mathrm{H}$. The cows belonging to this group also presented a lower protein concentration $(P<0.01)$ than that of the other groups.

Between the 1st and 12th week of lactation, the cows lost between 17 (group M) and $30 \mathrm{~kg}$ (group $\mathrm{H}$ ) of body mass (liveweight loss corrected for variations in digestive content, according to the method described by Chilliard et al, 1987), and 0.4 points of body score.
The increase in live weight between the fourth and fifth calving was important in all three groups $(+22,+15$ and $+9 \mathrm{~kg}$, respectively). This is partially linked to a gain in body score $(+0.6$ point between these two calvings in all three groups), but also to the difference in weight of digesta in the first week of lactation, linked to the difference in diets offered. Corrected for these differences, the increase in body mass is reduced, and nonsignificant (a mean of 10 kg over all 29 cows).

The increase in milk production between the fourth and fifth lactation was highest in group $L(+5.4 \mathrm{~kg} /$ day, $P<0.01)$ and lowest in group $\mathrm{M}(+1.9 \mathrm{~kg} / \mathrm{day}, P>0.10)$. In all 
three groups, the increase in peak production was more obvious, particularly in group $L$ (+7.4 kg/day) (table III).

These responses between lactations presented a wide range, mainly linked to the variability in energy intake increases, even intragroup (fig 1). Thus, the production of fat-corrected milk increased by $1 \mathrm{~kg}$ per supplementery UF between the fourth and fifth lactation.

\section{CONCLUSION}

Despite relatively reduced numbers, this trial demonstrates that cows submitted to undernutrition during four successive winters maintain a large milk production ability which develops even further with increased feeding level, but which depends, above all, on the intake capacity of the animals. It would seem, however, that there remains a residual effect of winter undernutrition of the preceding lactations of around 2.6 $\mathrm{kg}$ /day of milk between groups $\mathrm{H}$ and $\mathrm{L}$, even though the animals had been man-

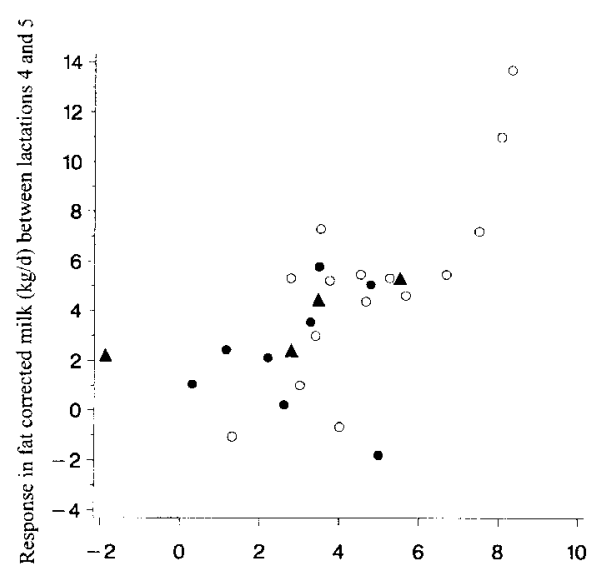

Change in energy supply (UFL/d) between lactations 4 and 5

Fig 1. Relationship between variations in energy supply and in milk yield during the first 12 weeks of lactation between the fourth and fifth lacta-

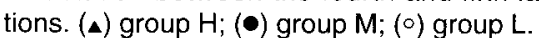

aged throughout all summer periods in the same way (ie, not strongly restrictive). These results confirm observations made previously (Wiktorsson, 1979; Broster et al, 1989; Berg and Ekern, 1993) over two lactations. Moreover, this trial reveals that animals fed according to their requirements during their first four lactations are still able to respond appreciably $(+3.3 \mathrm{~kg} /$ day of peak production) when fed even more liberally. In most animals, a large proportion of the supplementary energy ingested is employed in milk production.

\section{REFERENCES}

Berg J, Ekern A (1993) Long-term effects of concentrate level in dairy cows. Acta Agric Scand 43, 3543

Broster WH, Clements JA, Broster VJ, Smith T, Siviter JW, Hill RE (1989) Effect of amount and composition of feed given over three lactations on the performance of the dairy cow. J Dairy Res 56,561 577

Broster WH, Broster VJ, Clements AJ (1993) Feed utilization by the dairy cow over multiple lactations: a review. Livest Prod Sci 34, 1-21

Chilliard Y, Rémond B, Agabriel J, Robelin J, Vérité R (1987) Variations du contenu digestif et des réserves corporelles au cours du cycle gestation-lactation. Bull Techn CRZV Theix, INRA 70, 117-132

Coulon JB, D'Hour P, Garel JP, Petit M (1994) Level and pattern of winter concentrate allocation in dairy cows: results in first lactation cows. Anim Prod 59, 1120

Coulon JB, D'Hour P, Garel JP, Petit M (1996) Longterm effect of level and pattern of winter concentrate allocation. Ann Zootech 45, 233-251

Dulphy JP, Demarquilly C (1981) Problèmes particuliers aux ensilages. In: Prévision de la valeur nutritive des aliments des ruminants. Inra Éditions, Paris, 81 104

INRA (1989) Ruminant Nutrition. Recommended Allowances and Feed Tables (R Jarrige, ed), Inra and John Libbey Eurotext, Paris, France

Statistical Analysis Systems Institute (1987) SAS User's Guide: Statistics. SAS Institute Inc, Cary, NC, USA

Wiktorsson H (1979) General plane of nutrition for dairy cows. In: Feeding Strategy for the High Yielding Dairy Cow (WH Broster, H Swan, eds), Saint Albans, Granada, 149-169 